\title{
Lethal(2) Giant Larvae Protein Homolog 1
}

National Cancer Institute

\section{Source}

National Cancer Institute. Lethal(2) Giant Larvae Protein Homolog 1. NCI Thesaurus. Code $C 91768$.

Lethal(2) giant larvae protein homolog 1 (1064 aa, $115 \mathrm{kDa}$ ) is encoded by the human LLGL1 gene. This protein is involved in the structure of the actin cytoskeleton. 